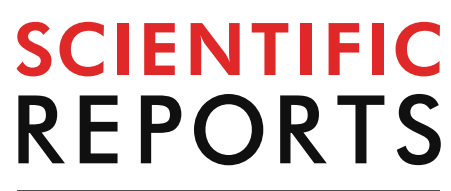

natureresearch

Check for updates

\title{
Morphological composition and fiber partitioning along regrowth in elephant grass CT115 intended for ethanol production
}

José A. Rueda $\left(1 \rrbracket\right.$, Juan de Dios Guerrero-Rodríguez $\mathbb{1}^{2} \llbracket$, Sergio Ramírez-Ordoñes $(1)$ Cecilio U. Aguilar-Martínez $\mathbb{1}^{1}$, Wilber Hernández-Montiel ${ }^{1}{ }^{1}$ \& Eusebio Ortega-Jiménez ${ }^{3 凶}$

Leaf share, plant age and growth season are often overlooked as modifiers of the biomass quality in energy crops. The current work studied the effect of the given factors on the biomass yield and the biomass quality in Elephant grass CT115, intended for bioethanol production, in Veracruz, Mexico. Two seasons per year, 5 months each, were tracked on a 2-weeks basis. The climate is warm wet with summer rains, $1,142 \mathrm{~mm}$ of annual rainfall, and $26^{\circ} \mathrm{C}$ monthly temperature. From day 56 of the wet season or from day 84 of the dry season, stems accumulated 12 or $6 \mathrm{Mg} \mathrm{ha}^{-1}$, respectively, while green leaves increased only $1 \mathrm{Mg}$. Higher biomass quality was recorded for the leaf fraction, or for the wet season regrowth. For instance, lignin contained in stems meant twice that of leaves, whereas stems recorded $20 \%$ less lignin in the wet season as compared to the dry season. Despite holocellulose being similar between fractions or seasons, hemicellulose and cellulose showed inverse correlation, while lignin and cellulose contents were directly correlated in stems. Increasing the annual harvest of green leaves will improve biomass quality, which is known to increase biodegradability and might improve the annual ethanol yield.

Second-generation ethanol derives from lignocellulosic raw materials, while first-generation ethanol derives from starch rich crops like corn or from sucrose rich crops such as sugarcane ${ }^{1}$. Despite the industrial production of second-generation biofuels yet being incipient; substantial research is being conducted for both production and conversion of raw materials ${ }^{2}$. Among the energetic crops, perennial grasses stand as the leading alternative, as their use overcome the major drawbacks of both the fossil fuels and the first-generation biofuels. For instance, they can recapture in only months the greenhouse gases emitted to the atmosphere when the ethanol produced from them is burnt ${ }^{3}$, plus their utilization may prevent the use of crops essential to human nutrition ${ }^{1}$. Elephant grass, Cenchrus purpureus (Schumach.) Morrone, has been widely studied as energy crop for the production of lignocellulosic ethanol. This grass yields above $45 \mathrm{Mg} \mathrm{ha}^{-1}$ under low input systems, while it may endure many harvests a year, therefore meaning a continuous supply of biomass for the ethanol industry ${ }^{4}$.

In elephant grass, green leaves yield $10 \%$ more ethanol than stems ${ }^{5}$. Nonetheless, the share of green leaves decreases as the crop ages ${ }^{6}$, while the leaf accumulation pattern may differ between growth seasons ${ }^{7,8}$. Since leaves play a key role in ethanol yield, both the accumulation and the chemical constitution of green leaves are considered with special emphasis.

Leaf accumulation follows a definite pattern. For instance, (1) the number of leaves in elephant grass varies within a known range depending on its management ${ }^{9}$, such number corresponds to eight to eleven green leaves ${ }^{6}$. Accordingly, (2) the leaf yield should become stable when the appearance of new leaves synchronizes the death of the oldest ${ }^{10}$. Finally, (3) once leaf mass approaches the yield plateau, the grass resources will be allocated to

${ }^{1}$ Universidad del Papaloapan, Campus Loma Bonita, Av. Ferrocarril SN Loma Bonita, CP 68400 Oaxaca, Mexico. ${ }^{2}$ Colegio de Postgraduados Campus Puebla, Km 125.5 Boulevard Forjadores de Puebla, CP 72760 Puebla, Mexico. ${ }^{3}$ Colegio de Postgraduados Campus Veracruz, Km 88.5 Carretera Xalapa-Veracruz, CP 91700 Veracruz, Mexico.『email: josearueda@yahoo.com; grjuan2000mx@yahoo.com; eortegaj@colpos.mx 
Wet season

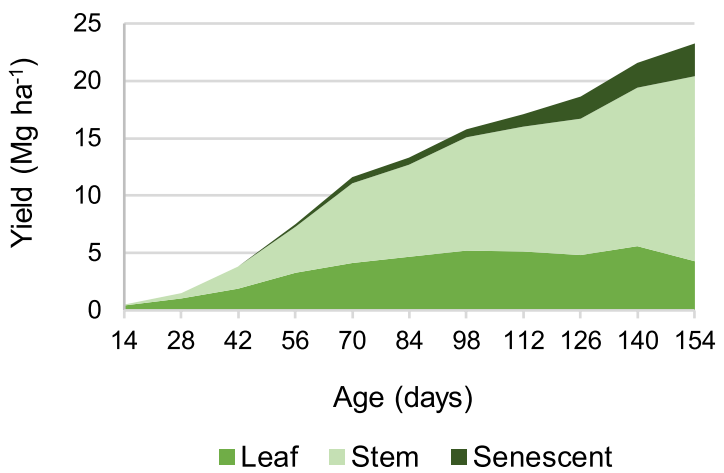

Dry season

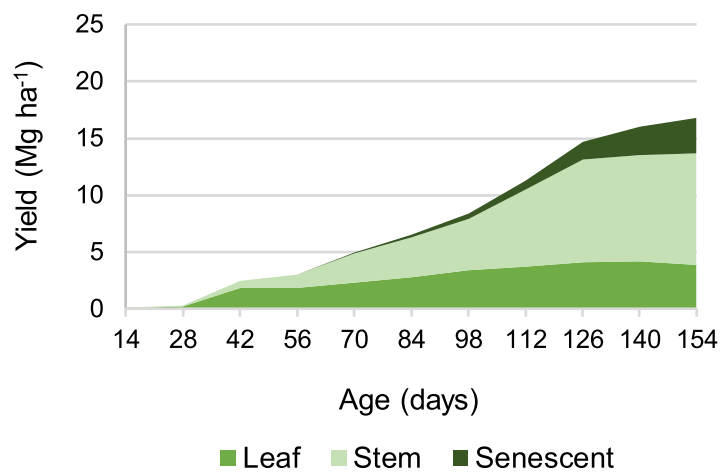

Figure 1. Yield by morphological fraction (piled to total yield) in elephant grass CT115, along 154 days of undisturbed regrowth, for the wet and dry seasons.

stem elongation driven by intraspecific competition ${ }^{9}$, so that green leaf accumulation may grow slower, which might limit the ethanol yield. For instance, in elephant grass, an increase of $35 \mathrm{Mg} \mathrm{ha}^{-1}$ in overall yield occurs at unvarying green leaf mass; therefore, green leaf accumulation has a biologic limit far smaller than that of stem ${ }^{6}$.

Elephant grass is far from being a unique raw material whose biomass quality remains constant. Apart from the within variety broad variation, which is the reason we undertook the current research, elephant grass has an enormous genetic diversity. Some attributes that have served the purpose of identifying and discriminating among genotypes involve those related to the chemical composition ${ }^{11}$, as well as some morphological features such as plant height, and number of tillers ${ }^{12}$.

Analytical methods used in the field of ruminant nutrition have allowed to understand both the chemical composition and the biodegradability of energy crops intended for bioethanol production ${ }^{13}$. In such approach, the fiber content is measured as the fraction of feedstocks which is insoluble in neutral detergent (such fraction named NDF). The combined content of cellulose and lignin corresponds to the fraction recovered after diluting a sample in acid detergent (such fraction named ADF) ${ }^{14}$, and the lignin content (named ADL) is assessed as the remnant from dilution in sulfuric acid ${ }^{15}$. In addition, hemicellulose and cellulose contents are estimated by subtracting $\mathrm{ADF}$ from NDF, or ADL from ADF, respectively.

Bioethanol yield is directly correlated to in vitro digestibility of the dry matter and inversely correlated to ADF and $\mathrm{ADL}$ contents ${ }^{5}$. Furthermore, the content of lignin, inherent to stem aging, has been proposed as the main factor limiting fiber digestibility ${ }^{16}$. Accordingly, higher digestibility ${ }^{17}$ and lower lignin content ${ }^{18}$, both leading to higher ethanol yield, converge in the leaf fraction ${ }^{5}$. In elephant grass, the content of most fiber components increase as the plant ages ${ }^{19}$, whereas such content may differ within ${ }^{19}$ and between ${ }^{7}$ growth seasons.

Variations in biomass quality due to plant age, plant composition, and season of regrowth are often overlooked in research works dealing with conversion of grass crops for bioethanol production. For instance, they merely mention the grass species ${ }^{20}$ or the fraction ${ }^{21}$. In fact, most studies on morphological and chemical composition of elephant grass deal with few age classes, a target growth height, or a fixed cutting frequency. In order to fill that gap of knowledge, the present study closely tracks the accumulation pattern and the fiber partition in both leaves and stems of elephant grass CT115, throughout five months of undisturbed regrowth, during the wet and dry seasons.

\section{Results and discussion}

Morphological composition. Yield is presented by season, fraction and regrowth age in Fig. 1. Overall biomass yield corresponds to the upper limit of the piled graphic. Leaf yield is shown at the base of the figure, in order to draw attention to the low relative variability in leaf yield across both seasons. When regrowth occurred under limiting weather conditions, leaf yield did not surpass $4 \mathrm{Mg} \mathrm{ha}^{-1}$. However, during the wet season, when higher soil moisture and higher temperature were available to promote regrowth, leaf yield reached $5 \mathrm{Mg} \mathrm{ha}^{-1}$. In growth cycles 154 days long, despite the leaf accumulation showing a biologic limit, stem accumulated $16 \mathrm{Mg} \mathrm{ha}^{-1}$ in the wet season or $10 \mathrm{Mg} \mathrm{ha}^{-1}$ in the dry season, whereas leaf proportion meant only $20 \%$ of the available biomass by day 154 in either season. Similar data for leaf proportion and leaf yield have been reported for elephant grass subjected to a single harvest per year ${ }^{22}$. However, management under long growth cycles implies reducing the annual harvest of green leaves across the year, as noticed in a previous work ${ }^{23}$.

Decisions on the utilization of elephant grass CT115 intended for ethanol production should focus on increasing the annual harvest of green leaves, in order to improve the yearly harvest of ethanol from a given field ${ }^{17,23}$. Cutting intervals under 70 days of regrowth might be established in order to prevent excessive stem accumulation. That in turn, according to a previous work, might increase both the leaf yield per harvest as well as the biomass yield per year ${ }^{23}$. The continuous stem accumulation, at relatively unvarying offer of green leaves, coincides with a previous study in which elephant grass is kept under undisturbed growth ${ }^{6}$. Furthermore, higher annual biomass yield has been reported for cutting intervals under three months, which also achieved a higher harvest of green leaves through the year ${ }^{23}$. 


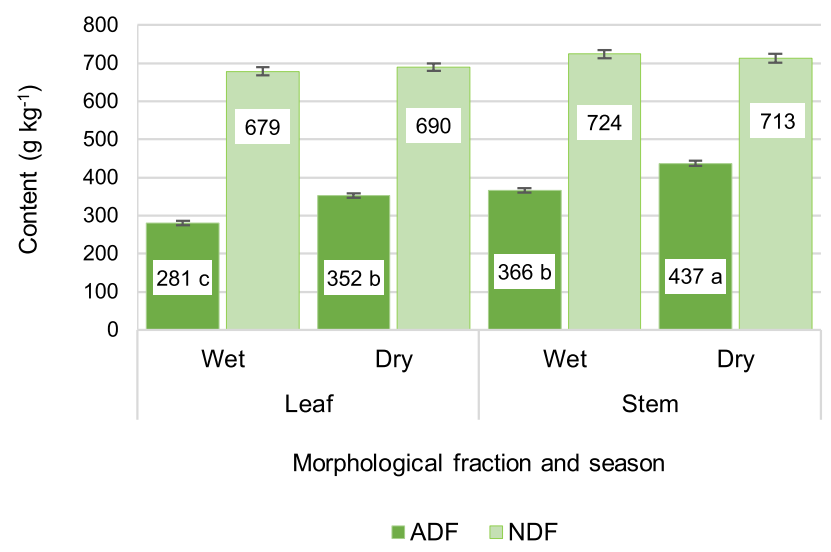

Figure 2. Acid detergent fiber (ADF) and neutral detergent fiber (NDF), averaged across 154 days of undisturbed regrowth, on a 14-days basis, in leaves and stems of elephant grass CT115, for the wet and dry seasons. Means with different letter are different at $\mathrm{P}<0.0001$ level, for ADF bars.

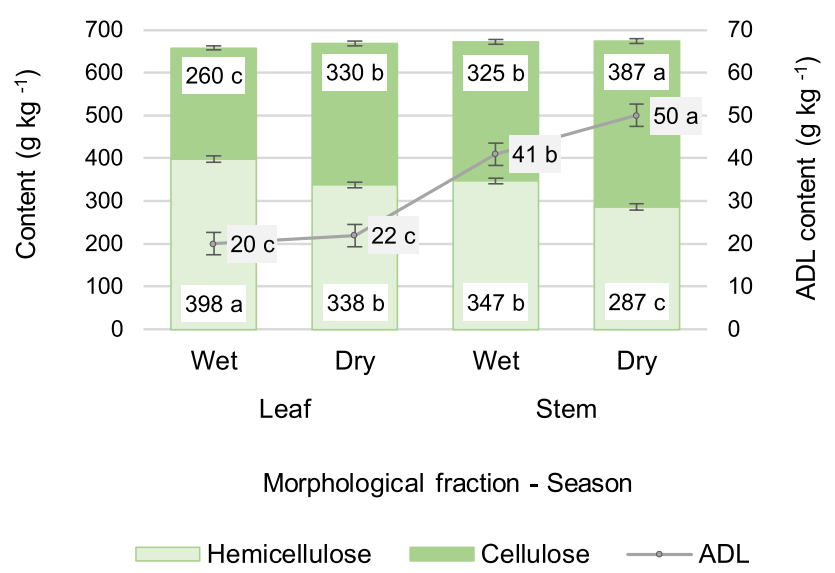

Figure 3. Hemicellulose, cellulose, holocellulose (combined-bar height), and acid detergent lignin (ADL) in leaves and stems of elephant grass CT115, during the wet and dry seasons. Average for eleven dates from day 14 to 154 , on a 14-days basis. Means with different letter within component, are different at $\mathrm{P}<0.0001$ level, while for ADL differences are validated at $\mathrm{P}<0.05$ level. Standard error bars are indicated for every mean.

Cutting intervals around 70 days might prevent useless stem accumulation and reduce the fiber content of the harvested biomass, therefore promoting a higher biodegradability ${ }^{24}$. Longer cutting intervals have been associated to a higher stem growth, a higher plant lignification, and lower biodegradability ${ }^{16}$.

Fiber partition as affected by season and fraction. Neutral detergent fiber (NDF) and acid detergent fiber (ADF) contents are shown in Fig. 2, whereas cellulose, hemicellulose and acid detergent lignin (ADL) contents are shown in Fig. 3, both organized by morphological component and season. Across season, the season-fraction interaction was not significant for NDF $(P=0.99)$, ADF $(P=0.94)$, hemicellulose $(P=0.97)$, cellulose $(\mathrm{P}=0.42)$, holocellulose $(\mathrm{P}=0.71)$, $\mathrm{ADL}(\mathrm{P}=0.17)$ or ashes $(\mathrm{P}=0.92)$ contents. In consequence, differences between seasons remain true within each fraction and differences between fractions remain true within each season. Leaf had $34 \pm 10.8 \mathrm{~g} \mathrm{~kg}^{-1}$ less NDF (mean \pm sed; $\left.\mathrm{P}=0.002\right), 85 \pm 9.5 \mathrm{~g} \mathrm{~kg}^{-1}$ less ADF $(\mathrm{P}<0.0001)$, $51 \pm 7.1 \mathrm{~g} \mathrm{~kg}^{-1}$ more hemicellulose, $61 \pm 5.1 \mathrm{~g} \mathrm{~kg}^{-1}$ less cellulose, $24 \pm 2.7 \mathrm{~g} \mathrm{~kg}^{-1}$ less ADL, and $28 \pm 5.9 \mathrm{~g} \mathrm{~kg}^{-1}$ more ashes, as compared to stem $(\mathrm{P}<0.0001)$. In addition, the wet season regrowth showed similar NDF $(\mathrm{P}=0.31)$ and ashes $(\mathrm{P}=0.40)$ contents, but $71 \pm 6.2 \mathrm{~g} \mathrm{~kg}^{-1}$ less $\mathrm{ADF}(\mathrm{P}<0.001), 60 \pm 7.1 \mathrm{~g} \mathrm{~kg}^{-1} \mathrm{more}$ hemicellulose, $66 \pm 5.1 \mathrm{~g} \mathrm{~kg}^{-1}$ less cellulose $(\mathrm{P}<0.0001)$ and $5.3 \pm 2.7 \mathrm{~g} \mathrm{~kg}^{-1}$ less $\mathrm{ADL}(\mathrm{P}<0.05)$ than the dry season regrowth. For information about the adjustment and significance of each explicative variable on the model, refer to Supplementary Tables.

Green leaf meant higher hemicellulose, but lower cellulose and lignin contents than stems. In fact, a high biodigestibility of the dry matter has been reported for leaves, as compared to stems, for the grasses Cynodon sp., Arundo donax, and Cenchrus purpureus ${ }^{5}$. In addition, higher digestibility and higher protein content have been reported for the leaves of Andropogon gayanus ${ }^{18}$. A higher hemicellulose concurs with a lower lignification 


\begin{tabular}{|c|c|c|c|c|c|c|c|c|}
\hline & \multicolumn{2}{|c|}{$\operatorname{NDF}\left(\mathrm{g} \mathrm{kg}^{-1}\right)$} & \multicolumn{2}{|c|}{ ADF $\left(\mathrm{g} \mathrm{kg}^{-1}\right)$} & \multicolumn{2}{|c|}{$\operatorname{ADL}\left(\mathrm{g} \mathrm{kg}^{-1}\right)$} & \multicolumn{2}{|c|}{ Ashes $\left(\mathrm{g} \mathrm{kg}^{-1}\right)$} \\
\hline & Leaf & Stem & Leaf & Stem & Leaf & Stem & Leaf & Stem \\
\hline \multicolumn{9}{|c|}{ Wet season } \\
\hline 14 & $539^{\mathrm{d}}$ & - & $227^{\mathrm{b}}$ & - & 23 & - & $123^{\mathrm{a}}$ & - \\
\hline 28 & $619^{A c}$ & $593^{\mathrm{Ad}}$ & $269^{\mathrm{Aab}}$ & $283^{\mathrm{Ac}}$ & $25^{\mathrm{A}}$ & $24^{\mathrm{Ae}}$ & $78^{\mathrm{Bb}}$ & $130^{\mathrm{Aa}}$ \\
\hline 42 & $693^{\mathrm{Aab}}$ & $690^{\mathrm{Ac}}$ & $305^{\mathrm{Ba}}$ & $333^{\mathrm{Ab}}$ & $20^{\mathrm{A}}$ & $15^{\mathrm{Ae}}$ & $60^{\mathrm{Bc}}$ & $69^{\mathrm{Ab}}$ \\
\hline 56 & $680^{\mathrm{Bb}}$ & $729^{\text {Aabc }}$ & $309^{\mathrm{Ba}}$ & $366^{\text {Aab }}$ & $31^{\mathrm{A}}$ & $38^{\mathrm{Abcd}}$ & $59^{A c}$ & $44^{\mathrm{Bc}}$ \\
\hline 70 & $700^{\text {Aab }}$ & $711^{\mathrm{Abc}}$ & $269^{\mathrm{Bab}}$ & $380^{\text {Aab }}$ & $16^{\mathrm{B}}$ & $34^{\mathrm{Acd}}$ & $63^{\mathrm{Abc}}$ & $24^{\mathrm{Bd}}$ \\
\hline 84 & $705^{\text {Aab }}$ & $715^{\mathrm{Abc}}$ & $273^{\text {Bab }}$ & $393^{\mathrm{Aa}}$ & $17^{\mathrm{B}}$ & $43^{\mathrm{Aabc}}$ & $65^{\mathrm{Abc}}$ & $22^{\mathrm{Bd}}$ \\
\hline 98 & $691^{\mathrm{Aab}}$ & $702^{\mathrm{Ac}}$ & $284^{\mathrm{Ba}}$ & $410^{\mathrm{Aa}}$ & $18^{\mathrm{B}}$ & $57^{\mathrm{Aa}}$ & $72^{\mathrm{Ab}}$ & $26^{\mathrm{Bd}}$ \\
\hline 112 & $720^{\mathrm{Aab}}$ & $735^{\text {Aabc }}$ & $302^{\mathrm{Ba}}$ & $375^{\mathrm{Aab}}$ & $18^{\mathrm{B}}$ & $54^{\mathrm{Aa}}$ & $66^{\mathrm{Abc}}$ & $33^{\mathrm{Bcd}}$ \\
\hline 126 & $733^{\mathrm{Ba}}$ & $771^{\mathrm{Aa}}$ & $300^{\mathrm{Ba}}$ & $384^{\mathrm{Aa}}$ & $19^{\mathrm{B}}$ & $44^{\mathrm{Aabc}}$ & $65^{\mathrm{Abc}}$ & $32^{\mathrm{Bcd}}$ \\
\hline 140 & $700^{\mathrm{Bab}}$ & $755^{\text {Aab }}$ & $289^{\mathrm{Ba}}$ & $374^{\text {Aab }}$ & $20^{\mathrm{B}}$ & $50^{\mathrm{Aabc}}$ & $65^{\mathrm{Abc}}$ & $24^{\mathrm{Bd}}$ \\
\hline 154 & $692^{\mathrm{Bab}}$ & $733^{\text {Aabc }}$ & $262^{\mathrm{Bab}}$ & $366^{\text {Aab }}$ & $19^{\mathrm{B}}$ & $53^{\mathrm{Aab}}$ & $67^{\mathrm{Ab}}$ & $20^{\mathrm{Bd}}$ \\
\hline se & 8.6 & 8.6 & 8.2 & 8.2 & 3.2 & 3.2 & 2.8 & 2.8 \\
\hline $\mathrm{R}^{2}$ & 0.98 & 0.98 & 0.98 & 0.98 & 0.96 & 0.96 & 0.99 & 0.99 \\
\hline \multicolumn{9}{|c|}{ Dry season } \\
\hline 14 & $622^{\mathrm{b}}$ & - & $328^{\mathrm{b}}$ & - & $28^{\mathrm{ab}}$ & - & $118^{\mathrm{a}}$ & - \\
\hline 28 & $627^{\mathrm{Bb}}$ & $662^{\mathrm{Ab}}$ & $339^{\mathrm{Bab}}$ & $404^{\text {Acd }}$ & $26^{\text {Aab }}$ & $27^{\mathrm{Ad}}$ & $112^{\mathrm{Ba}}$ & $130^{\mathrm{Aa}}$ \\
\hline 42 & $630^{\mathrm{Bb}}$ & $723^{\mathrm{Aab}}$ & $341^{\mathrm{Bab}}$ & $419^{\mathrm{Abcd}}$ & $25^{\mathrm{Aab}}$ & $21^{\mathrm{Ad}}$ & $85^{\mathrm{Ab}}$ & $70^{\mathrm{Bb}}$ \\
\hline 56 & $703^{\mathrm{Aab}}$ & $666^{\mathrm{Ab}}$ & $382^{\mathrm{Aab}}$ & $389^{\mathrm{Ad}}$ & $26^{\text {Aab }}$ & $29^{\mathrm{Acd}}$ & $77^{\mathrm{Abcd}}$ & $63^{\mathrm{Bb}}$ \\
\hline 70 & $748^{\mathrm{Aa}}$ & $751^{\text {Aab }}$ & $393^{\mathrm{Ba}}$ & $456^{\mathrm{Aabc}}$ & $32^{\mathrm{Ba}}$ & $44^{\mathrm{Ac}}$ & $70^{\text {Acde }}$ & $49^{\mathrm{Bc}}$ \\
\hline 84 & $681^{\mathrm{Aab}}$ & $689^{\mathrm{Ab}}$ & $350^{\mathrm{Bab}}$ & $417^{\mathrm{Abcd}}$ & $27^{\text {Bab }}$ & $49^{\mathrm{Ab}}$ & $79^{\mathrm{Abc}}$ & $47^{\mathrm{Bc}}$ \\
\hline 98 & $737^{\mathrm{Ba}}$ & $798^{\mathrm{Aa}}$ & $368^{\text {Bab }}$ & $487^{\mathrm{Aa}}$ & $20^{\mathrm{Bab}}$ & $63^{\mathrm{Aab}}$ & $68^{\text {Adef }}$ & $30^{\mathrm{Bd}}$ \\
\hline 112 & $729^{\mathrm{Aab}}$ & $733^{\mathrm{Aab}}$ & $347^{\text {Bab }}$ & $442^{\mathrm{Aabc}}$ & $12^{\mathrm{Bb}}$ & $60^{\mathrm{Aab}}$ & $60^{\text {Aefg }}$ & $32^{\mathrm{Bd}}$ \\
\hline 126 & $706^{\text {Bab }}$ & $760^{\mathrm{Aab}}$ & $341^{\mathrm{Bab}}$ & $464^{\mathrm{Aab}}$ & $17^{\mathrm{Bab}}$ & $66^{\mathrm{Aa}}$ & $57^{\mathrm{Afg}}$ & $21^{\text {Bde }}$ \\
\hline 140 & $713^{\text {Aab }}$ & $705^{\mathrm{Aab}}$ & $352^{\mathrm{Bab}}$ & $432^{\mathrm{Abcd}}$ & $17^{\text {Bab }}$ & $69^{A a}$ & $52^{\mathrm{Ag}}$ & $19^{\mathrm{Be}}$ \\
\hline 154 & $698^{\text {Bab }}$ & $756^{\mathrm{Aab}}$ & $339^{\mathrm{Bab}}$ & $462^{\mathrm{Aab}}$ & $13^{\mathrm{Bb}}$ & $74^{\mathrm{Aa}}$ & $53^{\mathrm{Ag}}$ & $20^{\mathrm{Be}}$ \\
\hline se & 18.0 & 18.0 & \begin{tabular}{|l|}
9.8 \\
\end{tabular} & 9.8 & 2.9 & 2.9 & \begin{tabular}{|l|}
1.9 \\
\end{tabular} & 1.9 \\
\hline $\mathrm{R}^{2}$ & 0.87 & 0.87 & 0.96 & 0.96 & 0.98 & 0.98 & 0.99 & 0.99 \\
\hline
\end{tabular}

Table 1. Neutral detergent fiber (NDF), acid detergent fiber (ADF), acid detergent lignin (ADL) and ashes contents in leaves and stems of elephant grass CT115, across 154 days of undisturbed regrowth, for the wet and dry seasons. se standard error, $R^{2}$ model adjustment. ${ }^{\mathrm{a}, \mathrm{b}, \ldots \mathrm{g}}$ Means in the same column with different lowercase letter are different $(\mathrm{P}<0.05) .{ }^{\mathrm{A}, \mathrm{B}}$ Means in the same row and variable with different uppercase letter are different $(\mathrm{P}<0.05)$.

and higher content of non-fiber soluble components, which could be converted to ethanol. Furthermore, a great number of research works had been addressed to the conversion of hemicellulose to ethanol ${ }^{25}$.

The higher content of biodegradable compounds as well as the lower cellulose and lignin contents recorded for the wet season regrowth, coincides with a previous study where elephant grass was managed at a cutting interval of 8 weeks throughout the year ${ }^{8}$. In addition, a higher in vitro digestibility, which is related to higher ethanol production ${ }^{5}$, was reported for the grass Andropogon gayanus grown in the wet season, as compared to the dry season regrowth ${ }^{18}$, which might imply a lower cell wall content (NDF). On the other hand, a study about variations in the chemical constitution of elephant grass between seasons found higher quality for the dry season regrowth ${ }^{7}$. This finding, which diverges from the current study, may be due to the important differences in the rainfall distribution throughout the year, since Indonesia is located in the Equator, and rainfall occurs to some extent in every month.

Holocellulose content was similar for the leaf and stem fractions $(663 \pm 7.1$ and $673 \pm 7.5, P=0.35)$. Likewise, it was similar for the wet and dry seasons $(665 \pm 7.3,671 \pm 7.3, \mathrm{P}=0.58)$. The given similarities occurred despite the wide inverse variations in cellulose and hemicellulose contents both between fractions and between seasons (Fig. 3). The leaf from the wet season averaged $138 \mathrm{~g} \mathrm{~kg}^{-1}$ more hemicellulose than cellulose, and the stem from the dry season showed $100 \mathrm{~g} \mathrm{~kg}^{-1}$ more cellulose than hemicellulose. Surprisingly, hemicellulose and cellulose contents were similar between the stem from the wet season and the leaf from the dry season (Fig. 3).

Fiber partition as affected by plant age. Fluctuations in NDF, ADF, ADL and ashes contents across each season are shown in Table 1, by morphological fraction: leaf and stem. In both seasons leaf fraction recorded less ADF since day 42 (except contents were alike on day 56 of the wet season), less ADL since day 70, and more ashes since day 56 or 42 of the wet and dry seasons, respectively. During the first 98 days of regrowth, NDF and ADF contents followed increasing trends in either season or either fraction; while they remained constant afterwards. 
Wet season

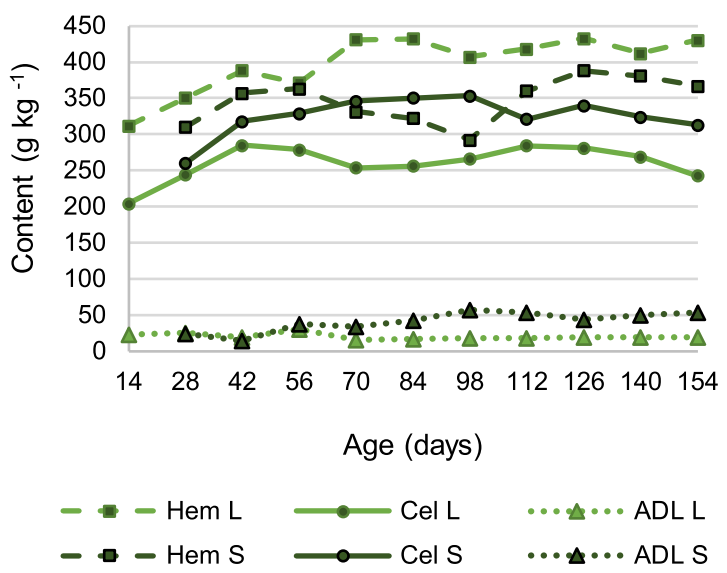

Dry season

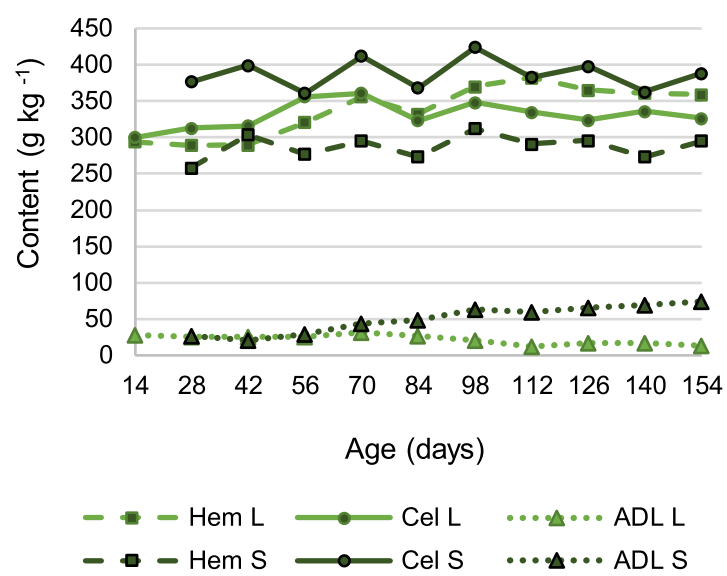

Figure 4. Within season variation in hemicellulose (Hem), cellulose (Cel), and acid detergent lignin (ADL) contents in leaves (L) and stems (S) of elephant grass CT115, during 154 days of undisturbed regrowth for the wet and dry seasons (starting in June or December, respectively).

ADL content increased through day 98 for the stem fraction in either season, whereas it remained constant for the leaf fraction, in both seasons, with one exception. (Table 1). Ash content declined across the two seasons, but decreased slower in leaf fraction.

Variations in hemicellulose, cellulose and ADL contents within each season are presented in Fig. 4, ordered by season, morphological fraction and age. Actual means and statistical differences for the visual information of such figure, are presented in Table 2. The higher hemicellulose and lower cellulose contents recorded for the leaf fraction across each season (Fig. 3) remained true virtually on every age in either season.

For the leaf fraction, hemicellulose content increased through day 70 of the wet season or through day 98 of the dry season, whereas the cellulose content increased through day 42 for the leaf fraction, in either season, and kept on similar records from then onwards. Regarding stem fraction, hemicellulose content increased only during the wet season, through day 56, then decreased, but it reached a second maximum on day 126 . Cellulose content was relatively constant in either season for the stem fraction, but reached a maximum on day 98 in both seasons.

The similar holocellulose content found between leaf and stem fractions on average across seasons (Fig. 3), remained true in ten out of the eleven ages, in either season. This was especially interesting, given that hemicellulose and cellulose contents differed between leaf and stem, virtually on every age class (Table 2).

A higher hemicellulose content for the leaf of elephant grass has been previously reported for the dry season, while a higher cellulose content has only been reported for the wet season; both results in a study in Thailand ${ }^{26}$, as an average for eight varieties of elephant grass. Climate and variety differences explain the discrepancies with the current work.

Published data are consistent with the fact that grass age and the content of most of the fiber constituents are directly related ${ }^{19,27,28}$; nonetheless, just a few age classes are usually included. Hemicellulose content has been reported to decrease for the whole plant of elephant grass in long-lasting growth cycles ${ }^{19}$. The current study gives rationale for such fact, since along regrowth, an increment of the stem proportion (Fig. 1), whose hemicellulose content was lower (Table 2), will lead to a lower hemicellulose content for the whole plant (see Supplementary Tables).

All seven variables describing chemical constitution in the current research work showed similar records from day 98 onwards, in each season and for each morphologic fraction.

Correlation between fiber fractions. Hemicellulose and cellulose contents were inversely correlated across the whole data $(\mathrm{r}=-0.58, \mathrm{P}<0.001)$, while such inverse correlation remained true within the leaf $(\mathrm{r}=-0.34, \mathrm{P}<0.026)$ or stem $(\mathrm{r}=-0.48, \mathrm{P}=0.001)$, as well as for the wet season alone $(\mathrm{r}=-0.33, \mathrm{P}=0.033)$; while a similar trend occurred for the dry season $(\mathrm{r}=-0.28, \mathrm{P}<0.071)$.

$\mathrm{ADL}$ and cellulose contents were directly correlated for the whole data $(\mathrm{r}=0.57, \mathrm{P}<0.001)$ and for the stem fraction $(r=0.387, P=0.015)$, but not for the leaf fraction $(r=0.12, P<0.42)$. Finally, ADL was inversely correlated with hemicellulose content for the whole data $(\mathrm{r}=-0.47, \mathrm{P}<0.001)$, or for the leaf fraction $(\mathrm{r}=-0.54, \mathrm{P}<0.001)$, but not for to stem fraction $(\mathrm{r}=-0.09, \mathrm{P}<0.54)$.

Recommendations. Biomass quality of elephant grass CT115 can be improved, by means of increasing both the share of green leaves and the share of the wet season regrowth, in the biomass harvested along the year. A higher biomass quality, will in turn increase the annual yield of ethanol per area unit.

Strategies to accomplish a higher quality of the harvested biomass, as proposed above, may involve (1) cutting intervals of around 56 days during the wet season or around day 70 during the dry season, and (2) reduce cutting intensity. The latter implies cutting to a greater height, so that the fodder left uncut in the field will facilitate 


\begin{tabular}{|c|c|c|c|c|c|c|}
\hline & \multicolumn{2}{|c|}{ Hemicellulose $\left(\mathrm{g} \mathrm{kg}^{-1}\right)$} & \multicolumn{2}{|c|}{ Cellulose $\left(\mathrm{g} \mathrm{kg}^{-1}\right)$} & \multicolumn{2}{|c|}{ Holocellulose $\left(\mathrm{g} \mathrm{kg}^{-1}\right)$} \\
\hline & Leaf & Stem & Leaf & Stem & Leaf & Stem \\
\hline \multicolumn{7}{|c|}{ Wet season } \\
\hline 14 & $312^{\mathrm{e}}$ & - & $204^{c}$ & - & $516^{\mathrm{e}}$ & - \\
\hline 28 & $350^{\mathrm{Ad}}$ & $310^{\text {Bde }}$ & $244^{\mathrm{Ab}}$ & $260^{\mathrm{Ac}}$ & $594^{\mathrm{Ad}}$ & $570^{\mathrm{Ad}}$ \\
\hline 42 & $388^{\mathrm{Abc}}$ & $357^{\text {Babc }}$ & $285^{\mathrm{Ba}}$ & $318^{\mathrm{Aab}}$ & $673^{\mathrm{Abc}}$ & $675^{\mathrm{Abc}}$ \\
\hline 56 & $371^{\mathrm{Acd}}$ & $363^{\mathrm{Bab}}$ & $279^{\mathrm{Bab}}$ & $329^{\mathrm{Aab}}$ & $649^{\mathrm{Bc}}$ & $692^{\mathrm{Ab}}$ \\
\hline 70 & $431^{\mathrm{Aa}}$ & $331^{\mathrm{Bbcd}}$ & $254^{\mathrm{Bab}}$ & $346^{\mathrm{Aab}}$ & $684^{\text {Aab }}$ & $677^{\mathrm{Abc}}$ \\
\hline 84 & $432^{\mathrm{Aa}}$ & $322^{\text {Bcde }}$ & $256^{\mathrm{Bab}}$ & $350^{\mathrm{Aab}}$ & $688^{\mathrm{Aab}}$ & $672^{\mathrm{Abc}}$ \\
\hline 98 & $407^{\text {Aab }}$ & $292^{\mathrm{Be}}$ & $266^{\mathrm{Bab}}$ & $353^{\mathrm{Aa}}$ & $673^{\mathrm{Abc}}$ & $645^{\mathrm{Ac}}$ \\
\hline 112 & $418^{\mathrm{Aab}}$ & $360^{\mathrm{Bab}}$ & $284^{\mathrm{Ba}}$ & $321^{\mathrm{Aab}}$ & $702^{\mathrm{Aab}}$ & $681^{\mathrm{Ab}}$ \\
\hline 126 & $433^{\mathrm{Aa}}$ & $388^{\mathrm{Ba}}$ & $281^{\mathrm{Bab}}$ & $340^{\mathrm{Aab}}$ & $714^{\mathrm{Aa}}$ & $727^{\mathrm{Aa}}$ \\
\hline 140 & $412^{\mathrm{Aab}}$ & $381^{\mathrm{Ba}}$ & $269^{\text {Bab }}$ & $324^{\mathrm{Aab}}$ & $680^{\mathrm{Aabc}}$ & $705^{\mathrm{Aa}}$ \\
\hline 154 & $430^{\mathrm{Aa}}$ & $367^{\mathrm{Bab}}$ & $243^{\mathrm{Bbc}}$ & $313^{\mathrm{Ab}}$ & $673^{\mathrm{Abc}}$ & $680^{\mathrm{Abc}}$ \\
\hline se & 6.4 & 6.4 & 6.7 & 6.7 & 7.2 & 7.2 \\
\hline $\mathrm{R}^{2}$ & 0.98 & 0.98 & 0.97 & 0.97 & 0.98 & 0.98 \\
\hline \multicolumn{7}{|c|}{ Dry season } \\
\hline 14 & $294^{\mathrm{b}}$ & - & $300^{c}$ & - & $594^{\mathrm{b}}$ & - \\
\hline 28 & $289^{\mathrm{Ab}}$ & $258^{\mathrm{B}}$ & $313^{\mathrm{Bbc}}$ & $377^{\mathrm{Abc}}$ & $602^{\mathrm{Ab}}$ & $635^{\mathrm{Ab}}$ \\
\hline 42 & $290^{\mathrm{Ab}}$ & $304^{\mathrm{A}}$ & $316^{\mathrm{Babc}}$ & $399^{\mathrm{Aabc}}$ & $606^{\mathrm{Bab}}$ & $703^{\mathrm{Aab}}$ \\
\hline 56 & $321^{\mathrm{Aab}}$ & $277^{\mathrm{B}}$ & $356^{\mathrm{Aab}}$ & $361^{\mathrm{Ac}}$ & $677^{\mathrm{Aa}}$ & $637^{\mathrm{Ab}}$ \\
\hline 70 & $356^{\mathrm{Aab}}$ & $295^{\mathrm{B}}$ & $361^{\mathrm{Ba}}$ & $412^{\mathrm{Aab}}$ & $716^{\mathrm{Aa}}$ & $707^{\mathrm{Aab}}$ \\
\hline 84 & $332^{\mathrm{Abc}}$ & $273^{\mathrm{B}}$ & $323^{\mathrm{Babc}}$ & $368^{\mathrm{Abc}}$ & $654^{\text {Aab }}$ & $640^{\mathrm{Ab}}$ \\
\hline 98 & $370^{\mathrm{Aa}}$ & $312^{\mathrm{B}}$ & $348^{\mathrm{Bab}}$ & $424^{\mathrm{Aa}}$ & $717^{\mathrm{Aa}}$ & $735^{\mathrm{Aa}}$ \\
\hline 112 & $382^{\mathrm{Aa}}$ & $291^{\mathrm{B}}$ & $335^{\mathrm{Babc}}$ & $383^{\mathrm{Aabc}}$ & $717^{\mathrm{Aa}}$ & $674^{\mathrm{Aab}}$ \\
\hline 126 & $365^{\mathrm{Aa}}$ & $296^{\mathrm{B}}$ & $324^{\mathrm{Babc}}$ & $398^{\mathrm{Aabc}}$ & $689^{\mathrm{Aa}}$ & $694^{\mathrm{Aab}}$ \\
\hline 140 & $361^{\text {Aab }}$ & $273^{\mathrm{B}}$ & $336^{\mathrm{Babc}}$ & $363^{\mathrm{Ac}}$ & $696^{\mathrm{Aa}}$ & $636^{\mathrm{Ab}}$ \\
\hline 154 & $359^{\mathrm{Aab}}$ & $295^{\mathrm{B}}$ & $326^{\mathrm{Babc}}$ & $388^{\mathrm{Aabc}}$ & $685^{\mathrm{Aa}}$ & $682^{\mathrm{Aab}}$ \\
\hline se & 10.7 & 10.7 & 8.0 & 8.0 & 16.4 & 16.4 \\
\hline $\mathrm{R}^{2}$ & 0.92 & 0.92 & 0.95 & 0.95 & 0.86 & 0.86 \\
\hline
\end{tabular}

Table 2. Hemicellulose, cellulose and holocellulose contents in leaf and stem of elephant grass CT115, across 154 days of undisturbed regrowth, for the wet and dry seasons. se standard error, $R^{2}$ model adjustment.

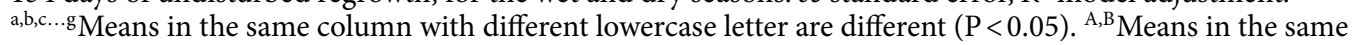
row and variable, with different uppercase letter are different $(\mathrm{P}<0.05)$. Hemicellulose content $=\mathrm{NDF}-\mathrm{ADF}$, cellulose content $=\mathrm{ADF}-\mathrm{ADL}$, and holocellulose $=$ hemicellulose + cellulose .

a faster restoration of the grass photosynthetic structures ${ }^{27}$. Nonetheless, such strategies may require further validation according to the wide diversity in climate conditions and crop management systems.

\section{Conclusions}

Elephant grass CT115 must be harvested by day 56 of the wet season or by day 70 of the dry season, in order to increase both the share of green leaves per harvest and the annual yield of green leaves.

Green leaves recorded more hemicellulose, less cellulose and less lignin than stems, whereas the regrowth from the wet season recorded more hemicellulose, less cellulose and less lignin, than that from the dry season. Holocellulose content was similar between leaves and stems of elephant grass, as well as between the regrowth from the wet season and that from the dry season.

When elephant grass is cultivated as energy crop for conversion to ethanol, leaves should be preferred over stems, whereas the wet season regrowth should be preferred over that from the dry season.

Age is the main factor affecting the chemical composition of elephant grass. Cutting intervals around 56 days for the wet season or around 70 days for the dry season provide an acceptable yield-quality balance. Longer intervals would sacrifice biomass quality, while shorter ones would sacrifice yield. The lower biomass quality of the late regrowth is explained in terms of both higher stem share and higher stem lignification.

Hemicellulose and cellulose contents were inversely correlated. In addition, ADL and hemicellulose contents were inversely correlated for the leaf fraction, while ADL and cellulose contents were directly correlated for the stem fraction.

\section{Methods}

Location and weather. The field assay was conducted at the Papaloapan Site of the Mexican Institute for Forestry, Agricultural and Livestock Research (INIFAP), Veracruz, Mexico. Climate is warm-wet with a summer rainy season, $1,142 \mathrm{~mm}$ of annual rainfall, and $25.8^{\circ} \mathrm{C}$ of monthly temperature ${ }^{29}$. Chemical determinations were 
carried out at the Laboratory of the Papaloapan University. Data for the present manuscript are permanently available online $\mathrm{e}^{30}$.

Planting and experimental conditions. This study was undertaken after establishment assessment ${ }^{31}$ and simultaneously to a tiller population dynamics study ${ }^{32}$, so that field methods for establishment are widely explained in such studies. Data collection for the wet seasons started on June 15, 2013 and June 7, 2014, while the dry season cycle started on December 7, 2013. The experimental unit was a plot with six rows, $8 \mathrm{~m}$ long and $0.6 \mathrm{~m}$ apart, for an area of $28.8 \mathrm{~m}^{2}$ by plot, and an effective plot of $16.8 \mathrm{~m}^{2}$, once discarding edges. Plots were distributed in four fully randomized blocks, given some field heterogeneity, two replications within every block were used. According to the Cotaxtla Laboratory of INIFAP, the soil is an orthic acrisol with sandy loam texture $^{33}$, characterized by low organic matter content $(0.34 \%)$, acidic $\mathrm{pH}$ (3.5), and limited contents of $\mathrm{N}, \mathrm{Ca}$, $\mathrm{Mg}$ and Cu.A 200:100:200 N, P and $\mathrm{K}\left(\mathrm{kg} \mathrm{ha}^{-1}\right.$ year $\left.^{-1}\right)$ fertilization formula was applied manually, half in the second week of regrowth, and the remaining half in the eighth week.

Yield and morphological composition. Yield and morphological composition were estimated as explained in a previous work $^{31}$, but methods are summarized here. From day 14 through day 154, and on a 2-week basis, a sample was cut from a $2 \mathrm{~m}$ long section of a central row, at $20 \mathrm{~cm}$ high, then weighed and recorded as sample fresh weight. A subsample was drawn from the sample and split into morphological fractions: stem, leaf and dead material. The fractions were placed on a paper bag tagged age, plot and fraction, and its weight was recorded the fraction fresh weight. The stems were sliced to $2 \mathrm{~cm}$ to enable drying. Paper bags were placed in a forced air oven for $96 \mathrm{~h}$ at $65^{\circ} \mathrm{C}$ and their weights were recorded as the fraction dry weight. Leaf, stem and dead material weights, combined within the plot, were added to obtain the subsample weight, first in fresh and then in dry basis. The fresh and $d r y$ weights were used to estimate the dry matter yield for each morphological fraction, while the subsample fresh and dry weights were extrapolated, first to the sample and then to a hectare, in order to estimate the dry matter yield $\left(\mathrm{Mg} \mathrm{ha}^{-1}\right)$.

Chemical composition. Oven-dried samples of stem and leaf were ground to $1 \mathrm{~mm}$ in a Wiley mill. A $2 \mathrm{~g}$ sample was fully dried at $105^{\circ} \mathrm{C}$ for $4 \mathrm{~h}$ to estimate dry matter, so that the contents could be expressed on dry basis. Ash content was measured by oven incineration of $1 \mathrm{~g}$ sample at $600{ }^{\circ} \mathrm{C}$ for $2 \mathrm{~h}^{34}$.

Neutral detergent fiber (NDF) and acid detergent fiber (ADF) contents were sequentially assessed using an Ankom 200 fiber analyzer ${ }^{14}$. Acid detergent lignin (ADL) content was measured by dilution in sulfuric acid ${ }^{15}$. Cellulose was estimated by subtracting ADF from NDF, hemicellulose was estimated by subtracting ADL from $\mathrm{ADF}$, and holocellulose was obtained by adding cellulose and hemicellulose.

Statistical analyses. Two models of analyses of variance were run for the fiber components. The first model included the whole data at once (Eq. 1), while the second model was used to study the variance occurring within each of the two seasons, separately (Eq. 2).

$$
\begin{gathered}
Y_{i j k}=\mu+S_{i}+F_{j}+S F_{i j}+\varepsilon_{i j k} \\
Y_{i j k}=\mu+A_{i}+F_{j}+A F_{i j}+\varepsilon_{i j k}
\end{gathered}
$$

Accordingly: $Y_{i j k}$ : data point or measurement, $\mu$ : overall mean for each given variable, $S_{i}$ : growth season, $F_{j}$ : morphological fraction, $S F_{i j}$ : season-by-fraction interaction, and $\varepsilon_{i j k}$ : error term for each data point. In the second model (Eq. 2), the given definitions remain; plus, the effects $A_{i}$ : age, and $A F_{i j}$ : age-by-fraction interaction. Analyses of variance were run by the MIXED procedure, and Tukey tests were carried out for the comparison between means. Finally, Pearson correlation coefficients were estimated between the variables regarding chemical composition. All three tests were run in SAS $9.4^{35}$.

\section{Data availability}

Data for the present manuscript has been made public and properly cited in the manuscript in Reference 16 (Rueda, J. A. Cenchrus purpureus. Figshare Dataset 2019). https://doi.org/10.6084/m9.figshare.11354201.v2.

Received: 2 February 2020; Accepted: 24 August 2020

Published online: 15 September 2020

\section{References}

1. FAO Forestry Department. Planted forests and second-generation biofuels (2009)

2. Padella, M., O'Connell, A. \& Prussi, M. What is still limiting the deployment of cellulosic ethanol? Analysis of the current status of the sector. Appl. Sci. 9, 4523 (2019).

3. Pawlowski, M., Meki, M. N., Kiniry, J. R. \& Crow, S. E. Carbon budgets of potential tropical perennial grass cropping scenarios for bioenergy feedstock production. Carbon Balance Manag. https://doi.org/10.1186/s13021-018-0102-8 (2018).

4. Singh, B. P., Singh, H. P. \& Obeng, E. Elephantgrass. In Biofuel Crops: Production, Physiology and Genetics (ed. Singh, B. P.) 270-290 (CAB International, Wallingford, 2013).

5. Anderson, W. F., Dien, B. S., Brandon, S. K. \& Peterson, J. D. Asseessment of bermudagrass and bunch grasses as feedstock for conversion to ethanol. Appl. Biochem. Biotechnol. 145, 13-21 (2008).

6. Woodard, K. R., Prine, G. M. \& Bachrein, S. Solar energy recovery by elephantgrass, energycane, and elephantmillet canopies. Crop Sci. 33, 824-830 (1993).

7. Evitayani, L., Warly, L., Fariani, A., Ichinohe, T. \& Fujihara, T. Seasonal changes in nutritive value of some grass species in West Sumatra, Indonesia. Asian Austral. J. Anim. Sci. 17, 1663-1668 (2004). 
8. Anindo, D. O. \& Potter, H. L. Seasonal variation in productivity and nutritive value of Napier grass at Muguga, Kenya. East Afr. Agric. For. J. 59, 177-185 (1994).

9. Duru, M. \& Ducrocq, H. Growth and senescence of the successive grass leaves on a tiller. Ontogenic development and effect of temperature. Ann. Bot. 85, 635-643 (2000).

10. Gautier, H., Varlet, G. C. \& Hazard, L. Tillering responses to the light environment and to defoliation in populations of perennial ryegrass (Lolium perenne L.) selected for contrasting leaf length. Ann. Bot. 83, 423-429 (1999).

11. Rocha, J. R. et al. Bioenergetic potential and genetic diversity of elephantgrass via morpho-agronomic and biomass quality traits. Ind. Crops Prod. 95, 485-492 (2017).

12. da Silva, V. B. et al. Assessment of energy production in full-sibling families of elephant grass by mixed models. Renew. Energy 146, 744-749 (2020).

13. Lorenz, A. J. et al. Forage quality and composition measurements as predictors of ethanol yield from maize (Zea mays L.) stover. Biotechnol. Biofuels 2, 1-8 (2009).

14. Van Soest, P. J., Robertson, J. B. \& Lewis, B. A. Methods for dietary fiber, neutral detergent fiber, and nonstarch polysaccharides in relation to animal nutrition. J. Dairy Sci. 74, 3583-3597 (1991).

15. Robertson, J. B. \& Van Soest, P. J. The detergent system of analysis. In The Analysis of Dietary Fiber in Foods (eds James, W. P. T. \& Theander, O.) 123-158 (Marcel Dekker, New York, 1981).

16. Buxton, D. R. \& Russell, J. R. Lignin constituents and cell-wall digestibility of grass and legume stems. Crop Sci. 28, 553 (1988).

17. Mowat, D. N., Fulkerson, R. S., Tossel, W. E. \& Winch, J. E. The in vitro digestibility and protein content of leaf and stem portions of forages. Can. J. Plant Sci. 45, 321-333 (1965).

18. Böhnert, E., Lascano, C. \& Weniger, J. H. Botanical and chemical composition of the diet selected by fistulated steers under grazing on improved grass-legume pastures in the tropical savannas of Colombia. II. Chemical composition of forage available and selected. J. Anim. Breed. Genet. 103, 69-79 (1986).

19. Na, C. I., Sollenberger, L. E., Fedenko, J. R., Erickson, J. E. \& Woodard, K. R. Seasonal changes in chemical composition and leaf proportion of elephantgrass and energycane biomass. Ind. Crops Prod. 94, 107-116 (2016).

20. Cardona, E., Rios, J., Peña, J. \& Rios, L. Effects of the pretreatment method on enzymatic hydrolysis and ethanol fermentability of the cellulosic fraction from elephant grass. Fuel 118, 41-47 (2014).

21. Wongwatanapaiboon, J. et al. The potential of cellulosic ethanol production from grasses in Thailand. J. Biomed. Biotechnol. 1, $1-10$ (2012).

22. Na, C. et al. Management of perennial warm-season bioenergy grasses. I. Biomass harvested, nutrient removal, and persistence responses of Elephantgrass and Energycane to harvest frequency and timing. BioEnergy Res. 8, 581-589 (2015).

23. Rengsirikul, K. et al. Effects of inter-cutting interval on biomass yield, growth components and chemical composition of napiergrass (Pennisetum purpureum Schumach) cultivars as bioenergy crops in Thailand. Grassl. Sci. 57, 135-141 (2011).

24. Woodard, K. R. \& Prine, G. M. Forage yield of elephantgrass as affected by harvest frequency and genotype. Agron. J. 83, 541-546 (1991).

25. Chandel, A. K. et al. Bioconversion of hemicellulose into ethanol and value-added products: commercialization, trends, and future opportunities. In Advances in Sugarcane Biorefinery 97-134 (2018).

26. Rengsirikul, K. et al. Biomass yield, chemical composition and potential ethanol yields of 8 cultivars of Napiergrass (Pennisetum purpureum Schumach.) harvested 3-monthly in central Thailand. J. Sustain. Bioenergy Syst. 3, 107-112 (2013).

27. Lounglawan, P., Lounglawan, W. \& Suksombat, W. Effect of cutting interval and cutting height on yield and chemical composition of King Napier Grass (Pennisetum purpureum $\times$ Pennisetum americanum). Procedia Soc. Behav. Sci. 8, 27-31 (2014).

28. Bayble, T., Melaku, S. \& Prasad, N. K. Effects of cutting dates on nutritive value of Napier (Pennisetum purpureum) grass planted sole and in association with Desmodium (Desmodium intortum) or Lablab (Lablab purpureus). Livest. Res. Rural Dev. 19, 1-11 (2007).

29. García, E. Modificaciones al sistema de clasificación climática de Köpen (Instituto de Geografía de la Universidad Autónoma de México, México, 2004).

30. Rueda, J. A. Cenchrus purpureus. Figshare https://doi.org/10.6084/m9.figshare.11354201.v2 (2019).

31. Rueda, J. A. et al. Growth, yield, fiber content and lodging resistance in eight varieties of Cenchrus purpureus (Schumach.) Morrone intended as energy crop. Biomass Bioenergy 88, 59-65 (2016).

32. Rueda, J. A., Ortega, J. E., Enríquez, Q. F. J., Palacios, R. E. \& Ramírez, O. S. Tiller population dynamics in eight cultivars of elephant grass during undisturbed growth. Afr. J. Range Forage Sci. 35, 109-119 (2018).

33. IUSS Working Group WRB. World Reference Base for Soil Resources 2014, update 2015. International soil classification system for naming soils and creating legends for soil maps. Soil Resources Reports no. 106. (Food and Agriculture Organization of the United Nations, 2015).

34. AOAC International. Official Methods of Analyses (19th) (AOAC International, Arlington, 2012).

35. SAS. SAS/STAT 9.1 Users guide. (SAS Institute Inc., 2004).

\section{Acknowledgements}

Authors wish to recognize the insights given by James Patrick Killough, from the Universidad del Papaloapan, with regard to the English edition of the present manuscript.

\section{Author contributions}

J.A.R. conducted the field work and made first proposal of the manuscript. E.O.J. was on charge of directing the project, told which variables should be measured and suggested main references. J.D.G.R. assisted figures and tables building and formatting. C.U.A.M. and S.R.O. assessed the laboratory samples and proposed the approach on the data analyses. E.O.J., J.A.R. and W.H.M. wrote the main manuscript. All authors approved the final version.

\section{Funding}

This research did not receive any specific grant from funding agencies in the public, commercial, nor from notfor-profit sectors.

\section{Competing interests}

The authors declare no competing interests.

\section{Additional information}

Supplementary information is available for this paper at https://doi.org/10.1038/s41598-020-72169-2.

Correspondence and requests for materials should be addressed to J.A.R., J.G.-R. or E.O.-J. 
Reprints and permissions information is available at www.nature.com/reprints.

Publisher's note Springer Nature remains neutral with regard to jurisdictional claims in published maps and institutional affiliations.

(c) (i) Open Access This article is licensed under a Creative Commons Attribution 4.0 International License, which permits use, sharing, adaptation, distribution and reproduction in any medium or format, as long as you give appropriate credit to the original author(s) and the source, provide a link to the Creative Commons licence, and indicate if changes were made. The images or other third party material in this article are included in the article's Creative Commons licence, unless indicated otherwise in a credit line to the material. If material is not included in the article's Creative Commons licence and your intended use is not permitted by statutory regulation or exceeds the permitted use, you will need to obtain permission directly from the copyright holder. To view a copy of this licence, visit http://creativecommons.org/licenses/by/4.0/.

(C) The Author(s) 2020 